\title{
Safety Challenges in Transportation in Nigeria - A Relative Risk Approach
}

\author{
Suleiman G. Purokayo ${ }^{1, *} \&$ James Zira Stephen ${ }^{1}$ \\ ${ }^{1}$ Modibbo Adama University of Technology, Yola, Nigeria \\ *Correspondence: Modibbo Adama University of Technology, Yola, Nigeria. E-mail: gambiyo@mautech.edu.ng
}

Received: February 9, $2020 \quad$ Accepted: April 14, $2020 \quad$ Online Published: July 25, 2020

doi:10.5430/wjss.v7n2p39 URL: https://doi.org/10.5430/wjss.v7n2p39

\begin{abstract}
This study investigates safety challenges in transportation in Nigeria across the six geopolitical zones of the country comprising South-South, South-East, North-West, North-Central, North-East and South-West geopolitical Zones. Both primary and secondary data were employed, and the Multinomial Logistic Regression Model, with specific adoption of the Relative Risk Ratio approach, is the method of analysis. The main concern is examination of exposed and unexposed commuters in the various locations to determine the degrees of exposure to risks associated with 'basket' of modes, state of infrastructures and specific risk factors, which account for the fatalities observed on the different roads under consideration. It is found that the six geopolitical zones have various degrees of risks exposure while North-West, North-Central and South-West zones showed significant risk difference between the exposed and the unexposed groups due to risk factors such as bad roads, road blockage/obstruction, kidnaping, unmaintained vehicles, overloading, over speeding and other forms of reckless use of the roads etc. The study recommends risk avoidance education to commuters as new strategies in vulnerable zones and increased deployment of well-trained community road marshals and other relevant security personnel to monitor situations and provide safety for road users. Also, a working transportation policy must be evolve to mitigate the risk factors highlighted above.
\end{abstract}

Keywords: transport safety, risk exposures, traffic volume, relative risks

\section{Introduction}

Safety challenges and risks are common features of Nigerian roads. It is evidenced by relatively high number of accidents, frequent armed robbery incidents and a rising wave of kidnapping on most highways - both urban and rural roads. According to figures on road accident statistics by the Federal Road Safety Corps (FRSC) - an established road marshals' outfit that monitors accidents and conditions of roads in Nigeria, 1,331 people died from roads related accidents in the second quarter of 2018 and 87 passengers kidnapped. This has placed safety concerns on the roads (NBS, 2018; Vanguard, 2018).

Consequently, traffic safety and increased dangers are very glaring on all categories of roads in Nigeria - whether it is on rural roads, state roads or federal highways. Increasing safety and security on the roads is an ever-present challenge from a realistic and practical point of view. The World Health Organization (WHO) has expressed concerns over lack of safe roads which in turn affects public health due to the negative impacts it has on individuals and communities. This is to say its impacts on households - which is the 'store house' of the required labor force for the productive sectors of the macro-economy - has far reaching implications on the socio-economic well-being of any society. "Road traffic injuries and deaths have a terrible impact on individuals" (Lords, 2014). For low income developing countries like Nigeria, the cost involved in the provision and maintenance of the required health facilities to save lives from accident related cases can be prohibitive. Needed developmental aspirations of communities suffer significant setback as a result of significant losses of productive resources and growth occasioned by high death rates from road accidents. The WHO (2013) graphical reports showed that the probability of road crash leading to death depends on the geographical location of an individual. In this regard, Africa has the highest risk probability of 24.1 per 100,000 population of likelihood of facing this challenge (Lords, 2014).

Measures that must be evolved to reduce the level of vulnerability of road users depends on the magnitude of the 
level of risks. As opined by Lords (2014), risk is the parameter for measuring levels of safety of the transportation system (Furian, Brandstätter, Kaiser \& Witzik,2016; Kozoil \& Gromek, 2017). To evolve a new transportation policy to mitigate some of the problems faced by stakeholders, certain factors must holistically be taken into consideration. Such factors include levels of road infrastructure in terms of the capacity and availability of roads network, the condition of such roads for the motoring public, the incidence of over speeding, behavior of drivers as road users and the engineering specification of roads by soil types. Other factors to consider include road problems such as armed robbery incidences, activities of armed kidnappers and roads inaccessibility on the part of stakeholders due to conflicts and insurgency especially in the northern parts of Nigeria; these should be the defining knowledge guiding formulation of new transport policy that may be fit to provide the required solutions. Kozoil and Gromek, 2017 viewed that lack of initiatives serves as important limitation to finding solutions for preventing traffic accidents. Most developing countries like Nigeria, lack such initiatives because they are constrained by low budgetary allocation for road maintenance, wrong behavior of commercial drivers, high level of corruption of road security personnel and lack of political will on the side of government officials, and these have contributed to the increase in roads fatalities.

Studies have been conducted adopting the relative risk ratio approach in employment studies, road transport and other studies (see for instance, Bassuk, Glass, \& Berkman, 1999; Robinson, 1989; Jianakoplos \& Bernasek, 1998; Sönmez \& Graefe, 1998; Turcotte, 2006; Wells, Mullin, Norton, Langley, Connor, Jackson, \& Lay-Yee, 2004). However, no study has so far been conducted on road safety challenges in Nigeria using the relative risk approach. The aim of this study is to examine road safety challenges in Nigeria using the relative risk approach.

The relative risk approach defines risk in terms of exposure to risks and non-exposures to risks. Relative Risk Ratio is the measure of the prevalence of exposed commuters' population (users) of any given roads in relation to the prevalence of non-users of such roads. The approach in this study is to group into six and define the peculiarities of roads in terms of particular risks relatively attributed to the six geopolitical zones of Nigeria. This will be the basis for comparison of risks between the regions.

\section{Method}

Contemporary road safety models are mainly on exposures and risk which are an essential part of humans, whether perceived or not. The current outlook is to examine the level of exposure to risks of road users in Nigeria. Data used in this study is based on an upgraded data from (Purokayo, 2015). The upgrade is for year 2018. Data are from both primary and secondary sources. Survey based on interviews conducted and administered questionnaires on 612 respondents from selected towns and locations on specific highways in six states in the North-east geopolitical zone, where insurgency is prevalent and adds to the concerns on road safety, provides the primary data. Secondary data is sourced from National Bureau of Statistics (NBS) and road safety agency in Nigeria, the Federal Road Safety Corps (FRSC) for the six geopolitical zones of Nigeria as presented in Figure 1. 


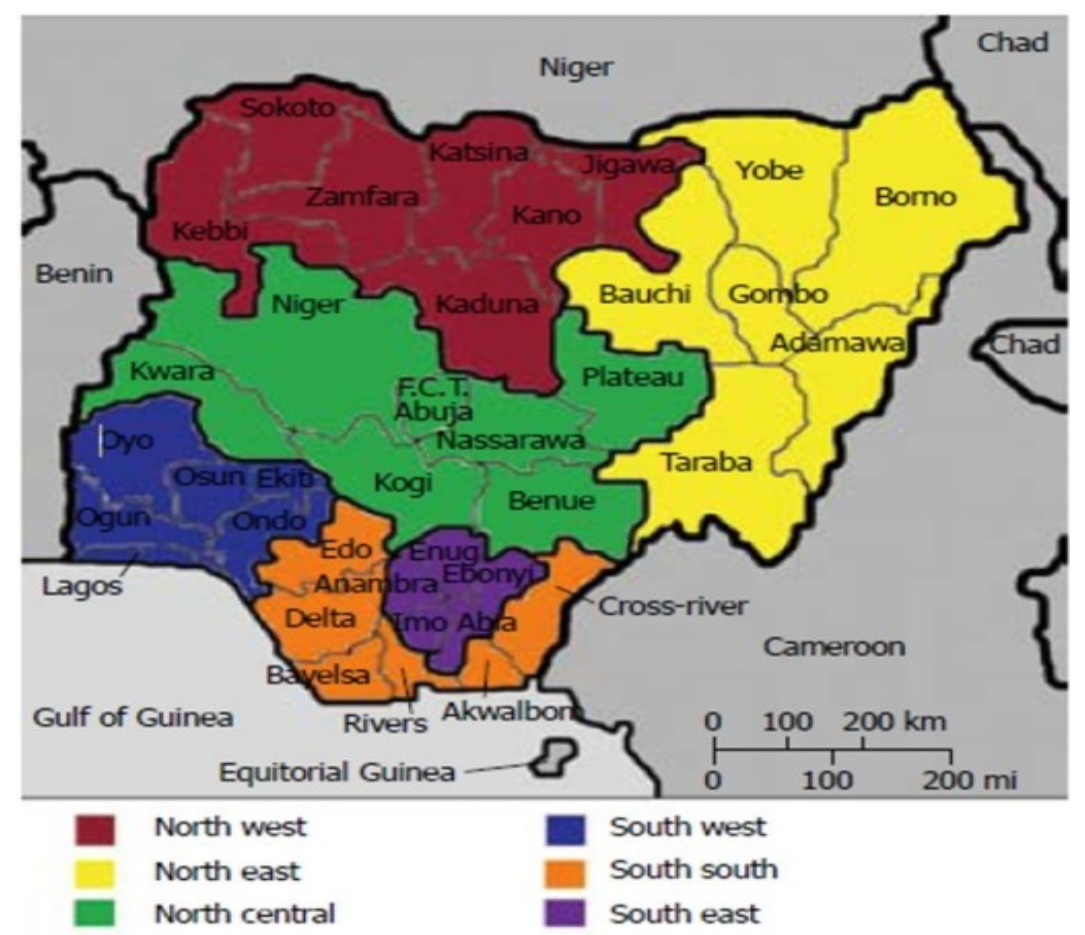

Figure 1. Road Types and Exposure to Risk

Source: https://www.researchgate.net/...

Figure 1 shows the six geopolitical zones in Nigeria along which roads type and risk peculiarity are categorized. It is important to state that the prevalence, incidence of risks and hazard exist in all locations. However, difference is in the magnitude, due to in part, neglected roads, increased commercial activities in some location that attract armed banditry and other vices.

The probabilities of a chosen alternative $\boldsymbol{j}$ rather than alternative $\boldsymbol{i}$, is shown by a simple logistic regression model:

$$
\frac{\operatorname{Pr}\left(y_{i}=j\right)}{\operatorname{Pr}\left(y_{i}=1\right)}=\exp \left(x_{i}^{\prime} \beta_{j}\right)
$$

It is the bases for determining relative risk. Even though initially it was for medical incidences, this was used by some authors (Zhang \& Yu, 1998). It was based on the definition of $\mathrm{Po}=$ prevalence of unexposed population, $\mathrm{P}_{1}=$ exposed population, 
Table 1. Level of Exposure to Risk

\begin{tabular}{|c|c|c|c|c|}
\hline $\begin{array}{l}\text { Level of Risk Exposure/ } \\
\text { Risk Factor }\end{array}$ & NW/NC Roads & $\begin{array}{l}\text { Northeast } \\
\text { Roads }\end{array}$ & Southwest Roads & $\begin{array}{l}\text { South-south/Southeast } \\
\text { Roads }\end{array}$ \\
\hline Bad segments of road & L. $\mathrm{H}$ & $\mathrm{H}$ & $\mathrm{L}, \mathrm{H}$ & $\mathrm{L}, \mathrm{H}$ \\
\hline $\begin{array}{l}\text { Topography (desert terrain, } \\
\text { forest roads, plateau in the } \\
\text { North Central regions etc.) }\end{array}$ & $\mathrm{H}$ & $\mathrm{H}$ & $\mathrm{H}$ & $\mathrm{L}$ \\
\hline Collusion of vehicles & $\mathrm{L}, \mathrm{H}$ & $\mathrm{L}$ & $\mathrm{L}, \mathrm{H}$ & $\mathrm{L}, \mathrm{H}$ \\
\hline $\begin{array}{l}\text { Road blockage/obstruction } \\
\text { due to insurgency/crisis/ } \\
\text { constructions }\end{array}$ & $\mathrm{L}$ & $\mathrm{H}$ & $\mathrm{L}$ & $\mathrm{L}$ \\
\hline Highway Kidnaping & $\mathrm{H}$ & $\mathrm{L}$ & $\mathrm{H}$ & $\mathrm{H}$ \\
\hline $\begin{array}{l}\text { Unmaintained Vehicles and } \\
\text { Overloading }\end{array}$ & $\mathrm{H}$ & $\mathrm{H}$ & $\mathrm{H}$ & $\mathrm{H}$ \\
\hline Traffic volume (daily) & $\mathrm{H}$ & $\mathrm{L}$ & $\mathrm{H}$ & $\mathrm{L}, \mathrm{H}$ \\
\hline
\end{tabular}

Level of Exposure: Low exposure (L) [1-5], Medium exposure (M) [6-8], High exposure (H) [9-10]

Source: Authors' estimation based on NBS statistics.

Table 1 shows level of exposure to risk on the scale of 1 to 10 according to the risk factors across the geopolitical zones in Nigeria. These roads include some of the major highways with high traffic. According to road agencies (FRSC, 2018), exposures as causative agents are many ranging from bad roads, obstruction and so on.

Most fatalities on Nigerian roads are due to the high volume of vehicular traffic and including heavy duty vehicles that turn out reckless on the roads. From the Northwest, the roads include Abuja - Kaduna and Kano-Kaduna highways, South-West, Lagos-Ibadan and South-South and South-East roads as shown on table 1.

Table 2. Road Traffic Crashes on State Basis (2nd quarter 2018) (totals for all the states by gender *)

\begin{tabular}{lccllc}
\hline $\begin{array}{l}\text { Number } \\
\text { Number Killed }\end{array}$ & of & & Injuries & Sustained \\
\hline SEX & Frequency & percentage & SEX & Frequency & Percentage \\
\hline Male Adult & 6151 & 73 & Male Adult & 1007 & 76 \\
Female Adult & 1795 & 21 & Female Adult & 250 & 19 \\
Male Child & 264 & 3 & Male Child & 40 & 3 \\
Female Child & 227 & 3 & Female Child & 34 & 3 \\
TOTAL & 8437 & 100 & 1331 & & 100 \\
\hline
\end{tabular}

Source: Federal Road Safety Corps (FRSC) (https://frsc.gov.ng/TRAFFIC)

Table 2 conveys the statistics of injuries and fatalities on the roads under investigation by sex and age as rearranged by the author.

\section{Results and Discussions}

In this paper safety challenges have connotations to all types of exposure to road accident - which is generally well-understood in road safety literature. "...... The various ways of measuring the amount of travel are referred to collectively as 'exposure data' because these data measure traveler's exposure to the risk of death or injury" (European Transport Safety Council [ETSC], 1999). Exposures to road mishaps is the parameter for comparison as seen on Tables 1, 2 and 3. 
Table 3. Relative Risk Ratio (RRR): Exposure by Roads Category

\begin{tabular}{llllll}
\hline Variable & \multicolumn{5}{c}{ Coefficient } \\
\hline & (Relative Risk Ratio) & Std. Err. & P-Value 95\% & Confidence Interval (CI) \\
\hline SS + SE roads & 808 & 107 & 0.108 & .621 & 1.053 \\
NW + NC Roads. & $569^{* * *}$ & .155 & 0.038 & .333 & .972 \\
SW Roads & $.660^{* * *}$ & .087 & 0.003 & .500 & .871 \\
NE Roads & 1.063 & .059 & 0.269 & .953 & 1.186 \\
\hline
\end{tabular}

Key: $\mathrm{SS}+\mathrm{SE}=$ South-South and South-East geopolitical Zones, $\mathrm{NW}+\mathrm{NC}=$ North-West and North-Central,

Geopolitical zones, $\mathrm{SW}=$ South-West geopolitical zone and $\mathrm{NE}=$ North-East geopolitical zone.

Source: Field Survey computation using Stata Software.

Table 3 shows the result of the computation of the Relative Risk Ratio (RRR). All the zones show that exposed commuters experience higher risks of fatality for using the roads than the unexposed who do not use them. Those exposed face 808,569, .660 and 1.06-times higher risk of fatality than those unexposed on the SS + SE, NW + NC, SW and NE roads respectively. Challenges on NE roads specifically is due to the high level of insurgency; the activities of Boko Haram (a terrorist group) have not only caused destruction to roads and bridges, but also hampered road maintenance in that zone. Also, road blockage and general insecurity of these roads are factors. Insurgency is a factor that is not measured, except for destruction to roads and bridges and how most roads are completely made dangerous and inaccessible (Purokayo, 2007). Roads in the SS+SE have degree of exposure and other factors that affects access to some economic location are crisis and ethnic conflict, for instance the Niger-Delta militancy and other conflicts that affects some parts of the regions.

However, we see that NW+ NC and SW are significantly exposed to risks of fatality than unexposed group if we take the levels of exposure to $\geq 0.05$ level of significance for these two geopolitical regions. This agrees with the computation in a study by a Belgian case-study as a standard for exposure to risks (Van den Bossche, Wets \& Brijs, 2005). To interpret the significance of the result from this study, we resort to interpreting the confidence interval. The null value of the confidence interval for the relative risk is one. If a 95\% Confidence Interval for the relative risk ratio includes the null value of 1 , then we have no sufficient evidence to conclude that the exposed and unexposed groups are statistically significantly different from each other.

The confidence interval of the relative risk of fatality of exposed commuters compared to unexposed group is between .333 and .9720 for NW + NC roads; and .500 and .871 for SW roads, and since the $95 \%$ confidence interval does not include the null value $(\mathrm{RRR}=1)$, the finding is statistically significant. We therefore conclude that exposed group are significantly different from unexposed group.

The risk factors that present the risks of fatality on Nigerian roads include bad segments of roads, topography (desert terrain, forest roads, plateau etc.), collusion of vehicles, road blockage/obstruction due to insurgency/crisis/constructions, highway Kidnaping, unmaintained vehicles and overloading, high traffic volume and over speeding and presence of reckless heavy duty vehicles on the highways.

\section{Conclusion and Recommendation}

Reducing road fatalities is a major challenge in monitoring safety on Nigerian roads, and much more, measures put in place towards managing traffic risks in terms of manpower needed for round-the-clock random checks of fatalities is vital. The standards for measuring exposure to risks, which results in fatalities, as the computation by the Belgian case-study, have been good reference for exposure incidence for policy and management of various levels exposure to injuries or deaths.

Designing strategies for handling critical safety risk challenges in the six geopolitical zones of Nigeria goes beyond normal routine security checks, but demands security and community policing to stem the cases of kidnaping and high rate of death and loss of millions of Naira on our roads. Most roads are impassable or with low access in North-East, North-West and North-Central roads, and results to death and injuries. The study recommends risk avoidance education to commuters as new strategies in vulnerable zones and increased deployment of well-trained community road marshals and other relevant security personnel to monitor situations and provide safety for road users. Also, a working transportation policy must evolve to address the issues of bad roads, road 
blockage/obstruction, kidnaping, unmaintained vehicles, overloading, over speeding and other forms of reckless use of the roads etc., to have safer highways with reduced fatality risks in Nigeria.

\section{References}

Bassuk, S. S., Glass, T. A., \& Berkman, L. F. (1999). Social disengagement and incident cognitive decline in community-dwelling elderly persons. Annals of internal medicine, 131(3), 165-173. https://doi.org/10.7326/0003-4819-131-3-199908030-00002

ETSC (1999). Exposure data for travel risk assessment: Current practice and future needs in theEU. European Transport Safety Council, Brussels, Belgium.

Federal Road Safety Corp (FRSC) (2018). Road transport data-second quarter. Retrieved from https://frsc.gov.ng/TRAFFIC

Furian, G., Brandstätter, C., Kaiser, S., \& Witzik, A. (2016). Subjective safety and risk perception. ESRA thematic report, 5. ESRA project (European Survey of Road Users' Safety Attitudes). Vienna, Austria: Kuratorium für Verkehrssicherheit.

Jianakoplos, N. A., \& Bernasek, A. (1998). Are women more risk averse? Economic Inquiry, 36(4), 620-630. https://doi.org/10.1111/j.1465-7295.1998.tb01740.x

Kozoil, J., \& Gromek, P. (2017). Creating safety in transport - traffic risk approach. Science Direct, Procedia Engineering, 192, 457-462. https://doi.org/10.1016/j.proeng.2017.06.079

Lords D. (2014). Application of accident prediction models for computation of accident risk on transportation network. Transport Research Record: Journal of Transportation Board, 1784(1), 17-26. https://doi.org/10.3141/1784-03

National Bureau of Statistics (2018). Road accidents in Q2. Retrieved from http://www.Punching.com

Purokayo, G. S. (2015). Economic implications of transport on the Nigerian economy: A study of road transport choice and cost of doing business ( $\mathrm{PhD}$. Thesis). Universiti Utara Malaysia. Electronic thesis published online by Universiti Utara Malaysia.

Purokayo, S. G. (2017). Mobiliuty challenges and border routes: The rise of regional conflicts in the Lake Chad Basin. Retrieved from http://www. Oapub.Org

Robinson, J. C. (1989). Exposure to occupational hazards among Hispanics, Blacks and non-Hispanic Whites in California. American journal of public health, 79(5), 629-630. https://doi.org/doi.org/10.2105/AJPH.79.5.629

Sonmez, S. F., \& Graefe, A. R. (1998). Determining future travel behavior from past travel experience and perceptions of risk and safety. Journal of Travel Research, 37(2), 171-177. https://doi.org/10.1177/004728759803700209

Turcotte, M. (2006). Like commuting? Workers' perceptions of their daily commute. Canadian Social Trends, Catalogue, 82, 35-40.

Van den Bossche, F., Wets, G., \& Brijs, T. (2005). Role of Exposure in Analysis of Road Accidents: A Belgian Case Study. Transportation Research Record: Journal of the Transportation Research Board, 1908, 96-103. https://doi.org/10.3141/1908-12

Vanguard (2018). Armed bandits kidnappers. Retrieved from http://www.vanguardngr.com

Wells, S., Mullin, B., Norton, R., Langley, J., Connor, J., Jackson, R., \& Lay-Yee, R. (2004). Motorcycle rider conspicuity and crash related injury: case-control study. Bmj, $328(7444), \quad 857$. https://doi.org/10.1136/bmj.37984.574757.ee

World Health Organization (2013). Road safety: Basic facts. Retrieved from http://ww.who.int/violence_injury_prevention/.../road

Zhang, J., \& Yu, K. F. (1998). What is the relative risk? A method of correcting the odds ratio in the cohort studies of common outcomes. JAMA, 280, 1690-1691. https://doi.org/10.1001/jama.280.19.1690 